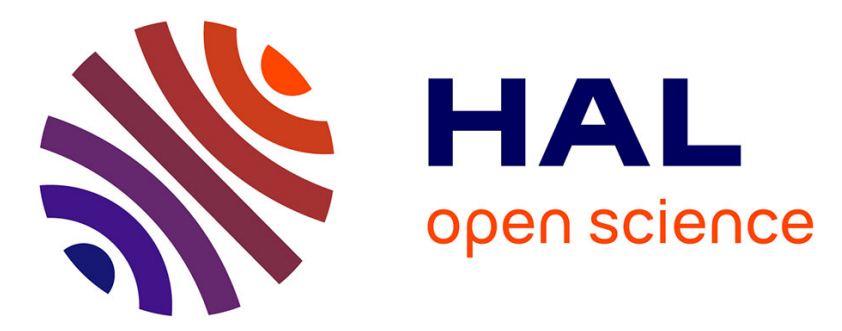

\title{
Construction of a Synthetic Antibody Gene Library for the Selection of Intrabodies and Antibodies.
}

Déborah Caucheteur, Gautier Robin, Vincent Parez, Pierre Martineau

\section{To cite this version:}

Déborah Caucheteur, Gautier Robin, Vincent Parez, Pierre Martineau. Construction of a Synthetic Antibody Gene Library for the Selection of Intrabodies and Antibodies.. Methods in Molecular Biology, 2017, Phage Display, 1701, pp.239-253. 10.1007/978-1-4939-7447-4_12 . hal-01653294

\section{HAL Id: hal-01653294 \\ https://hal.science/hal-01653294}

Submitted on 1 Dec 2017

HAL is a multi-disciplinary open access archive for the deposit and dissemination of scientific research documents, whether they are published or not. The documents may come from teaching and research institutions in France or abroad, or from public or private research centers.
L'archive ouverte pluridisciplinaire HAL, est destinée au dépôt et à la diffusion de documents scientifiques de niveau recherche, publiés ou non, émanant des établissements d'enseignement et de recherche français ou étrangers, des laboratoires publics ou privés. 


\section{Construction of a Synthetic Antibody Gene Library for}

\section{the Selection of Intrabodies and Antibodies}

Déborah Caucheteur, Gautier Robin, Vincent Parez and Pierre Martineau

IRCM, Institut de Recherche en Cancérologie de Montpellier, Montpellier, F-34298, France; INSERM, U1194, Montpellier, F-34298, France; Université de Montpellier, Montpellier, F-34090, France; Institut régional du Cancer de Montpellier, Montpellier, F-34298, France.

Corresponding author: Pierre Martineau ; pierre.martineau@ inserm.fr ; Web: http://www.ircm.fr/

\section{Summary}

Libraries of antibody fragments displayed on filamentous phages have proved their value to generate human antibodies against virtually any target. We describe here a simple protocol to make large and diverse libraries based on a single or a limited number of frameworks. The approach is flexible enough to be used with any antibody format, either single-chain (scFv, VHH) or multichain (Fv, Fab, (Fab')2), and to target in a single step the six complementarity-determining regions - or any other part - of the antibody molecule. Using this protocol, libraries larger than $10^{10}$ can be easily constructed in a single week.

\section{Key Words}

Kunkel mutagenesis, antibody fragment, single-chain Fv, phage-display, synthetic library 


\section{Running Head}

\section{Construction of a synthetic scFv library}

\section{Introduction}

With more than fifty molecules already registered, human monoclonal antibodies (mAbs) have proved their value as therapeutic molecules in numerous pathologies (1-3). These mAbs are usually obtained through three main technologies $(4,5)$ : mice immunization followed by hybridoma generation, and then in vitro humanization; transgenic mice genetically engineered for producing human antibodies (6); in vitro methods such as phage, ribosome or yeast-display (7). The displaybased methods present several advantages over the animal-based ones, in particular their low cost, high flexibility, and high speed, and for therapeutic applications, their ability to directly generate human antibodies and human-mouse cross-reacting mAbs for the pre-clinical characterizations in rodent models.

Among the display methods, phage-display is currently the most widely used approach and has proved to be a cheap and robust technology. This is particularly the case when a naive library is used, since a single antibody source is used for all the projects. For simple selections, antibodies against any target can be identified in about two weeks and the method can be automated and run in parallel with several antigens (8). However, few naive and diverse phage-display libraries are publicly available and the first step is thus to develop your own antibody source. For this critical step, you can rely on the natural diversity of human-recombined antibodies by cloning them from a collection of healthy human donors, or you can design the library using structural and sequence informations and build it in vitro using molecular biology techniques (9-12). The former has the advantage of using natural genes but requires many steps and human donors, whereas the latter only uses in vitro techniques but requires a careful design to obtain efficient libraries. 
Most of the phage-displayed libraries use antibody fragments like scFv, Fab or VHH fused to the g3p filamentous phage capsid protein. In addition, most authors use a phagemid since it is easier to manipulate than phages and essentially results in a monovalent display of the antibody fragment, allowing a more stringent selection than the multivalent display obtained when using phage vectors. Since the pioneering work of Dr. Kabat (13), it is well known that most of the diversity of the antibody molecule is found in the six complementarity-determining regions (CDRs), three being located in each chain. Because of their critical role in the antibody-antigen interaction, these six regions are the main target for randomization in most synthetic library designs. However, the average contribution of the six CDRs to the binding energy is very variable, the heavy chain CDR2 and CDR3 being the main contributors, and the light chain CDR2 only rarely interacting with the antigen. In addition, there is also a strong bias in the amino-acid distribution in the natural antibody paratopes with a high abundance of tyrosine residues. Using these informations may lead to more clever library designs but this requires a flexible mutagenesis method to construct them (11).

In this protocol, we will describe the construction of a synthetic library, based on a unique framework. We will add diversity in the 6 CDR loops and length variations in the VH CDR3. The protocol is based on the well known site-directed mutagenesis method developed by Dr. Kunkel (14). The main interest of this approach is that the library is constructed in a single step using a pool of randomized oligonucleotides, and can address any antibody format. We will introduce diversity in the six CDRs but the protocol can be easily adapted to also introduce diversity to framework regions, to a more restricted number of positions, or using a restrained amino-acid code.

\section{Materials}

All buffers must be prepared with ultra-pure water and ACS grade chemicals, and stored at room temperature unless otherwise indicated. 


\subsection{Common Materials}

1. Ampicillin and/or Carbenicillin stock at $100 \mathrm{mg} / \mathrm{mL}$ (see Note 1). Store at $-20{ }^{\circ} \mathrm{C}$.

2. Chloramphenicol stock at $30 \mathrm{mg} / \mathrm{mL}$ in ethanol. Store at $-20{ }^{\circ} \mathrm{C}$.

3. Kanamycin stock at $25 \mathrm{mg} / \mathrm{mL}$ in $\mathrm{H}_{2} \mathrm{O}$. Sterilize by filtration and store at $-20{ }^{\circ} \mathrm{C}$.

4. 2xYT medium. In $900 \mathrm{~mL}$ of $\mathrm{H}_{2} \mathrm{O}$, dissolve $16 \mathrm{~g}$ of Tryptone (Peptone), $10 \mathrm{~g}$ of yeast extract, and $5 \mathrm{~g}$ of $\mathrm{NaCl}$, adjust $\mathrm{pH}$ to 7.0 with $5 \mathrm{~N} \mathrm{NaOH}$, and then the volume to 1 liter. Autoclave and store at RT.

5. $40 \%$ glucose solution. Sterilize by autoclaving. Store at RT.

6. LB plates. In $900 \mathrm{~mL}$ of $\mathrm{H}_{2} \mathrm{O}$, dissolve $10 \mathrm{~g}$ of Tryptone (Peptone), $5 \mathrm{~g}$ of yeast extract, and $10 \mathrm{~g}$ of $\mathrm{NaCl}$, adjust $\mathrm{pH}$ to 7.0 with $5 \mathrm{~N} \mathrm{NaOH}$, and then the volume to 1 liter. Add $15 \mathrm{~g}$ of agar and autoclave. Allow the solution to cool to $55-60{ }^{\circ} \mathrm{C}$ before adding supplements, and then pour the plates. LB/GA plates, add $50 \mathrm{~mL}$ of $40 \%$ glucose solution and $1 \mathrm{~mL}$ of ampicillin $(100 \mu \mathrm{g} / \mathrm{mL}) ; \mathrm{LB} / \mathrm{C}$ plates, add $500 \mu \mathrm{L}$ of Chloramphenicol $(15 \mu \mathrm{g} / \mathrm{ml})$; LB/GAC plates, add $50 \mathrm{~mL}$ of $40 \%$ glucose solution, $1 \mathrm{~mL}$ of ampicillin, and $500 \mu \mathrm{L}$ of Chloramphenicol.

7. KM13 helper phage (15) stock at $10^{14} \mathrm{pfu} / \mathrm{mL}$ (see Note 2$)$. Store at $-70{ }^{\circ} \mathrm{C}$.

8. PEG/NaCl solution: $20 \%$ (w/v) PEG, $2.5 \mathrm{M} \mathrm{NaCl}$ in $\mathrm{H}_{2} \mathrm{O}$. Autoclave and store at $4{ }^{\circ} \mathrm{C}$ (see Note 3).

9. PBS x10. In $900 \mathrm{~mL}$ of $\mathrm{H}_{2} \mathrm{O}$, dissolve $80 \mathrm{~g}$ of $\mathrm{NaCl}(1370 \mathrm{mM}), 2 \mathrm{~g}$ of $\mathrm{KCl}(27 \mathrm{mM}), 11.5$ $\mathrm{g}$ of $\mathrm{Na}_{2} \mathrm{HPO}_{4} \cdot 7 \mathrm{H}_{2} \mathrm{O}(43 \mathrm{mM}), 2 \mathrm{~g}$ of $\mathrm{KH}_{2} \mathrm{PO}_{4}(15 \mathrm{mM})$, adjust volume to 1 liter, autoclave and store at RT.

10. Macherey Nagel NucleoSpin plasmid kit and NT2 buffer (see Note 4).

11. $50 \mathrm{~mL}$ conical centrifuge tubes (see Note 5) and a refrigerated centrifuge.

12. $1.5 \mathrm{~mL}$ microcentrifuge tubes and a refrigerated bench-top centrifuge (see Note 6). 


\subsection{Preparation of Uracil-Containing Single-Stranded DNA Template}

1. E. Coli K12 CJ236: $\mathrm{F} \Delta($ HindIII $)::$ cat $\left(\mathrm{Tra}^{+} \mathrm{Pil}^{+} \mathrm{Cam}^{\mathrm{R}}\right) /$ ung-1 relAl dut-1 thi-1 spoT1 mcrA (see Note 7).

2. A phage or phagemid containing your antibody gene (see Note 8). In the protocol below we will use pHEN1 phagemid vector (17) containing the scFv13R4 (18).

3. Uridine stock. $6 \mathrm{mg} / \mathrm{mL}$ in $\mathrm{H}_{2} \mathrm{O}$, sterilize by filtration, and store at $-20{ }^{\circ} \mathrm{C}$.

\subsection{Synthesis of the Mutagenized Complementary Strand}

1. Stock at $100 \mu \mathrm{M}$ of the $5^{\prime}$-phosphorylated mutagenenic primers in Tris- $\mathrm{HCl} \mathrm{pH} 8$ / EDTA $1 \mathrm{mM}$ (Figure 1) (see Note 9). Store at $-20^{\circ} \mathrm{C}$.

2. NEB2 x10 buffer (1x: $10 \mathrm{mM}$ Tris-HCl pH7.9@25 ${ }^{\circ} \mathrm{C}, 50 \mathrm{mM} \mathrm{NaCl}, 10 \mathrm{mM} \mathrm{MgCl} 2,1$ mM DTT). Store at $-20{ }^{\circ} \mathrm{C}$.

3. dNTPs (25 mM each). Store at $-20^{\circ} \mathrm{C}$.

4. T4 DNA Ligase $(5 \mathrm{u} / \mu \mathrm{L})$ and $10 \mathrm{x}$ buffer (400 mM Tris- $\mathrm{HCl}, 100 \mathrm{mM} \mathrm{MgCl} 2,100 \mathrm{mM}$ DTT, $5 \mathrm{mM}$ ATP, $\mathrm{pH} 7.8$ at $25^{\circ} \mathrm{C}$; Thermofisher).

5. T7 DNA Polymerase (NEB, $10 \mathrm{u} / \mu \mathrm{L})$.

\subsection{Preparation of Electrocompetent Bacteria}

1. E. Coli TG1 (see Note 10).

2. $500 \mathrm{~mL}$ centrifuge bottles.

3. Sterile magnetic stir bars.

4. Magnetic stirrer.

5. HEPES 1M: weight $2.38 \mathrm{~g}$ of HEPES, add $8 \mathrm{~mL}$ of $\mathrm{H}_{2} \mathrm{O}$, adjust $\mathrm{pH}$ to 7.0 and the volume to $10 \mathrm{~mL}$. Sterilize by filtration. Store at $4{ }^{\circ} \mathrm{C}$.

6. Glycerol/HEPES: Weight $10 \mathrm{~g}$ of glycerol, make up to 1 liter with water, autoclave. Add 1 $\mathrm{mL}$ of sterile HEPES $1 \mathrm{M}$, store at $4{ }^{\circ} \mathrm{C}$. 
7. $\mathrm{H}_{2} \mathrm{O} / \mathrm{HEPES}$ : Add $1 \mathrm{~mL}$ of sterile HEPES $1 \mathrm{M}$ to 1 liter of autoclaved ultra-pure water, store at $4{ }^{\circ} \mathrm{C}$.

\subsection{Electroporation and Phage Production}

1. SOC medium. In $950 \mathrm{~mL}$ of $\mathrm{H}_{2} \mathrm{O}$, dissolve $20 \mathrm{~g}$ of tryptone (peptone), $5 \mathrm{~g}$ of yeast extract, $0.5 \mathrm{~g}$ of $\mathrm{NaCl}, 10 \mathrm{~mL}$ of $250 \mathrm{mM} \mathrm{KCl}(18.6 \mathrm{~g} / \mathrm{l})$. Make up to 1 liter with water, adjust $\mathrm{pH}$ to 7.0 with $5 \mathrm{~N} \mathrm{NaOH}$, autoclave. Before use, add $5 \mathrm{~mL}$ of sterile $2 \mathrm{M} \mathrm{MgCl}_{2}(190.4 \mathrm{~g} / \mathrm{l}$, autoclaved) and $9 \mathrm{~mL}$ of sterile $40 \%$ glucose $(20 \mathrm{mM})$.

2. $14 \mathrm{ml}$ sterile polypropylene round-bottom culture tubes $(17 \mathrm{~mm} \times 100 \mathrm{~mm})$.

3. Biorad GENE PULSER II and $0.2 \mathrm{~cm}$ gap cuvettes (see Note 11 ).

4. Sterile Pasteur pipettes.

\section{Methods}

\subsection{Preparation of Uracil-Containing Single-Stranded DNA Template}

In this protocol, we will first infect a dut ung strain with our phagemid, we then make a stock of phages using KM13 helper phage, and finally purify the single stranded DNA (ssDNA) encapsided in the phage particles. This ssDNA will contain uracil instead of thymine and will be used in the next protocol.

1. Pick a single fresh colony of CJ236 in $2 \mathrm{~mL}$ of $2 \mathrm{xYT}$ and grow overnight $(\mathrm{ON})$ at $37^{\circ} \mathrm{C}$ with shaking.

2. Add $20 \mu \mathrm{L}$ of the pre-culture in $2 \mathrm{~mL}$ of $2 \mathrm{xYT}$.

3. Grow with vigorous agitation at $37{ }^{\circ} \mathrm{C}$ until the $\mathrm{OD}_{600 \mathrm{~nm}}$ reaches 0.5 .

4. Add $10 \mu \mathrm{L}$ of a pHEN1-13R4 phage stock diluted to $10^{6} \mathrm{cfu} / \mathrm{mL}$ (see Note 12 ).

5. Incubate $1 \mathrm{~h}$ at $37^{\circ} \mathrm{C}$ without or with a slow shaking $(0-100 \mathrm{rpm})$.

6. Plate $100 \mu \mathrm{L}$ on $\mathrm{LB} / \mathrm{GAC}$ plates and incubate $\mathrm{ON}$ at $37^{\circ} \mathrm{C}$ (see Note 13 ). 
7. Pick a colony in $2 \mathrm{~mL}$ of $2 \mathrm{xYT}$ with $2 \%$ glucose and $100 \mu \mathrm{g} / \mathrm{mL}$ Ampicillin and grow ON at $37{ }^{\circ} \mathrm{C}$ with agitation.

8. Add $20 \mu \mathrm{L}$ of the pre-culture in $2 \mathrm{~mL}$ of $2 \mathrm{xYT}$ with $2 \%$ glucose and $100 \mu \mathrm{g} / \mathrm{mL}$ Ampicillin and grow with vigorous agitation until $\mathrm{OD}_{600 \mathrm{~nm}}$ reaches 0.5 .

9. Add $20 \mu \mathrm{L}$ of a $1 / 100^{\text {th }}$ dilution of the KM13 helper phage $\left(10^{12} \mathrm{pfu} / \mathrm{mL}\right)$ (see Note 14$)$.

10. Incubate without shaking for 30 min at $37^{\circ} \mathrm{C}$ (see Note 15 ).

11. Centrifuge at $4{ }^{\circ} \mathrm{C}$ for $15 \mathrm{~min}$ at $3,000 \mathrm{~g}$.

12. Discard the supernatant.

13. Resuspend the pellet in $30 \mathrm{~mL}$ of $2 \mathrm{xYT}$ with $25 \mu \mathrm{g} / \mathrm{mL}$ of Kanamycin and $100 \mu \mathrm{g} / \mathrm{mL}$ of Ampicillin supplemented with $0.25 \mu \mathrm{g} / \mathrm{mL}$ of Uridine (1.25 $\mu \mathrm{L}$ of stock solution).

14. Grow $\mathrm{ON}$ with vigorous agitation $(220-240 \mathrm{rpm})$ at $37{ }^{\circ} \mathrm{C}$ in a $150 \mathrm{~mL}$ flask.

15. Transfer in a $50 \mathrm{~mL}$ conical centrifuge tube.

16. Centrifuge for $10 \mathrm{~min}$ at $12,000 \mathrm{~g}$ at $2{ }^{\circ} \mathrm{C}$ ( see Note 5).

17. Transfer the $30 \mathrm{~mL}$ of supernatant containing the phages into a $50 \mathrm{~mL}$ centrifuge tube.

18. Add $8 \mathrm{~mL}$ of cold $\mathrm{PEG} / \mathrm{NaCl}$ solution and mix thoroughly by inverting the tube several times.

19. Incubate for $30 \mathrm{~min}$ at $4{ }^{\circ} \mathrm{C}$ on ice with regular mixing.

20. Centrifuge for $10 \mathrm{~min}$ at $12,000 \mathrm{~g}$ at $2{ }^{\circ} \mathrm{C}$.

21. Remove the supernatant by inverting the tube with caution and put it gently upside down on absorbent paper to remove excess liquid (see Note 16).

22. Spin briefly and remove the remaining liquid with a pipette and using absorbent paper as in the previous step.

23. Resuspend the phage pellet in $0.5 \mathrm{~mL}$ of PBS using an aerosol-free tip (see Note 17) and transfer it in a $1.5 \mathrm{~mL}$ microcentrifuge tube. 
24. Centrifuge at $4{ }^{\circ} \mathrm{C}$ for $5 \mathrm{~min}$ at $16,000 \mathrm{~g}$ in a bench-top centrifuge to pellet any insoluble material (see Note 18).

25. Purify the ssDNA from the supernatant using Macherey Nagel NucleoSpin plasmid kit using the supplementary protocol for the isolation of M13 DNA (see Note 4).

26. Elute the ssDNA in $100 \mu \mathrm{L}$ of $5 \mathrm{mM}$ Tris-HCl, $\mathrm{pH} 8.5$ (kit AE buffer).

27. Quantify the ssDNA in a spectrophotometer (see Note 19).

28. Store the purified ssDNA at $-20^{\circ} \mathrm{C}$.

\subsection{Synthesis of the Mutagenized Complementary Strand}

Diversity in the library is introduced using degenerate oligonucleotides. The pool of phosphorylated oligonucleotides is first hybridized to the single-stranded template prepared in section 3.1, then theses oligonucleotides are used as primers and elongated using T7 polymerase, and finally the gaps closed using T4 DNA ligase. This results in a double-stranded circular DNA with a uracil-containing strand coding a wild-type $\mathrm{scFv}$ gene and a thymine-containing strand coding for the $\mathrm{scFv}$ library. Each reaction prepared in this section will be used in a single electroporation experiment (section 3.4) and should generate between $5 \times 10^{8}$ and $5 \times 10^{9}$ clones. We usually make the following reaction independently for each VH-CDR3 loop length (5-10 lengths) to generate a large library of at least $5 \times 10^{9}$ clones.

1. Annealing of the mutagenic primers to the ssDNA template

- $\quad$ Prepare a primer mix in $\mathrm{H}_{2} \mathrm{O}$, each primer at a $10 \mu \mathrm{M}$ final concentration (see Note 20): $10 \mu \mathrm{L}$ of each primer in a final volume of $100 \mu \mathrm{L}$ of $\mathrm{H}_{2} \mathrm{O}$.

- Prepare an oligonucleotide:template mix with a 6:1 molar ratio: 12.5 pmoles of uracilcontaining ssDNA $(26 \mu \mathrm{g} \sim 25 \mu \mathrm{L}), 7.5 \mu \mathrm{L}$ of the primer mix (75 pmoles of each primer), $25 \mu \mathrm{L}$ of NEB2 10x, and $\mathrm{H}_{2} \mathrm{O}$ up to $250 \mu \mathrm{L}$ (see Note 21 ).

- Transfer to a thermal cycler at $90{ }^{\circ} \mathrm{C}$ for $2 \mathrm{~min}, 4{ }^{\circ} \mathrm{C} 10 \mathrm{~s}, 45^{\circ} \mathrm{C}$ for $20 \mathrm{~min}$, and $20^{\circ} \mathrm{C}$ for $10 \mathrm{~min}$ (see Note 22). Store at $4{ }^{\circ} \mathrm{C}$. 
2. Add in the following order to the $250 \mu \mathrm{L}$ of annealed oligonucleotide:template mix

- $\quad 13 \mu \mathrm{L} \mathrm{H} \mathrm{H}_{2} \mathrm{O}$ (final volume of $350 \mu \mathrm{L}$ )

- $\quad 40 \mu \mathrm{L}$ dNTPs (2.9 mM final) (see Note 23)

- $\quad 35 \mu \mathrm{L}$ 10x Ligase buffer (1x final)

- $8 \mu \mathrm{L}$ T4 DNA ligase (40 Weiss units)

- $\quad 4 \mu \mathrm{L}$ T7 DNA Polymerase (40 units)

3. Incubate at $20^{\circ} \mathrm{C}$ for 5 hours (h).

4. Purify DNA on a NucleoSpin Plasmid column using the "Plasmid DNA clean-up" procedure (see Note 24).

5. Elute the DNA in $40 \mu \mathrm{L}$ of $\mathrm{AE}$ buffer $(5 \mathrm{mM}$ Tris/ $\mathrm{HCl}, \mathrm{pH} 8.5)$ heated to $70{ }^{\circ} \mathrm{C}$ to maximize yield (see Note 25).

6. Optional. Run an agarose gel to check the efficiency of the second-strand synthesis.

- Pour a 1\% agarose gel without any intercalating agent using TAE buffer (see Note 26).

- Analyze $2 \mu \mathrm{L}$ of your mutagenesis in parallel with the same amount of ssDNA $(\sim 0.5$ $\mu \mathrm{L})$.

- Run the gel for $1 \mathrm{~h}$ at $5 \mathrm{~V} / \mathrm{cm}$.

- Incubate the gel for 30-60 min in a solution of TAE with $10 \mu \mathrm{g} / \mathrm{mL}$ of SYBR Safe DNA Gel Stain (see Note 27). A typical result is shown in Figure 2.

\subsection{Preparation of Electrocompetent Bacteria}

Use freshly-prepared electrocompetent cells following the protocol below in order to obtain the high transformation efficiency (typically $5.10^{9}-2.10^{10}$ transformants/ $\mu \mathrm{g}$ of supercoiled pUC18 plasmid) required for the final library transformation (see Note 28). 
1. All material must be pre-cooled and kept as close to $4{ }^{\circ} \mathrm{C}$ as possible in an ice/water bath throughout the preparation (see Note 29). If possible, work in a cold room. The centrifuge and the rotor must be pre-cooled to $4{ }^{\circ} \mathrm{C}$.

2. Pick a fresh colony of TG1 in a $50 \mathrm{~mL}$ flask containing $10 \mathrm{~mL}$ of $2 \mathrm{xYT}$, and grow $\mathrm{ON}$ at $37^{\circ} \mathrm{C}$ with vigorous shaking $(220 \mathrm{rpm})($ see Note 10$)$.

3. Pour the flask content in a 5 liter flask containing 1 liter of $2 \mathrm{xYT}$, and grow at $37{ }^{\circ} \mathrm{C}$ with vigorous shaking (220-240 rpm) until $\mathrm{OD}_{600 \mathrm{~nm}}$ reaches 0.7 .

4. Pour the flask content in two $500 \mathrm{~mL}$ centrifuge bottles and cool down in an ice/water bath for $30 \mathrm{~min}$. Mix regularly and gently the bottles.

5. Centrifuge at 5,000 $\mathrm{g}$ for $5 \mathrm{~min}$ at $4{ }^{\circ} \mathrm{C}$ and discard the supernatant.

6. Add a cold and sterile magnetic stir bar and $500 \mathrm{~mL}$ of cold $\mathrm{H}_{2} \mathrm{O} / \mathrm{HEPES}(1 \mathrm{mM})$ to each bottle. Resuspend the pellet using a magnetic stirrer. Start with a vigorous stirring until the pellet detaches from the bottle; continue with a slower rotation rate until all the bacteria are completely resuspended. You may also gently mix the bottle by turning it upside down several times.

7. Centrifuge at $5,000 \mathrm{~g}$ for $10 \mathrm{~min}$ at $4{ }^{\circ} \mathrm{C}$ and discard the supernatant gently, carefully avoiding to disturb the pellet containing the stir bar.

8. Repeat steps 6 and 7.

9. Resuspend, as in step 6, in $50 \mathrm{~mL}$ of cold glycerol/HEPES. Pool the two bottles in a new centrifuge bottle. Do not transfer the stir bars.

10. Centrifuge at $5,000 \mathrm{~g}$ for $15 \mathrm{~min}$ at $2{ }^{\circ} \mathrm{C}$ and discard the supernatant.

11. Resuspend the pellet in $1 \mathrm{~mL}$ of cold glycerol/HEPES using a cold $10 \mathrm{~mL}$ pipette. The final volume should be around $2 \mathrm{~mL}$. (see Notes 30). 


\subsection{E. Coli Electroporation and Phage Production}

If you prepared your own electrocompetent cells in section 3.3, you must immediately proceed and electroporate your DNA since transformation efficiency will decrease if cells are frozen. Each mutagenesis prepared in step 5 of section 5 will generate, in a single electroporation experiment, between $5 \times 10^{8}$ and $5 \times 10^{9}$ clones. In this protocol, we directly make the stock of phages that can be then used in phage display experiments. With the volumes used below, we typically obtain enough aliquots for 1500 selections.

1. Prepare one sterile $50 \mathrm{~mL}$ centrifuge tube for each DNA preparation (section 5) containing $12 \mathrm{~mL}$ of SOC and two $14 \mathrm{~mL}$ sterile polypropylene culture tubes containing $0.95 \mathrm{~mL}$ of SOC.

2. Warm these tubes to $37^{\circ} \mathrm{C}$ for at least $1 \mathrm{~h}$.

3. Cool on ice: 1 electroporation cuvette for each DNA preparation, and 1 for the positive control; the same number of sterile microcentrifuge tubes; and the slide that holds the cuvette in the electroporator (see Note 31).

4. In a pre-chilled microcentrifuge tube, mix $350 \mu \mathrm{L}$ of competent cells and the purified ligation (35-40 $\mu \mathrm{L}$, prepared in step 5 of section 5). Do not pipet up and down to mix since this will warm the cells.

5. Transfer the mix in a pre-chilled electroporation cuvette. Be sure to put the sample at the bottom of the cuvette by gently taping the bottom of the cuvette on a flat surface, and avoid introducing bubbles. Quickly wet the cuvette and the cuvette slide with absorbent paper, then assemble them in the electroporator.

6. Apply an electric pulse using the following conditions: $2,500 \mathrm{~V}, 25 \mu \mathrm{F}, 200 \Omega$.

7. Immediately transfer the cells to one of the pre-warmed sterile $50 \mathrm{~mL}$ centrifuge tube containing $12 \mathrm{~mL}$ of SOC by washing the sample with $1 \mathrm{~mL}$ of outgrowth medium using a Pasteur pipette. (see Note 32). 
8. Immediately transfer the tube to a $37^{\circ} \mathrm{C}$ incubator and shake vigorously $(220 \mathrm{rpm})$ for $1 \mathrm{~h}$.

9. Repeat steps 4-8 with the other synthesized DNA.

10. Negative control: Add $40 \mu \mathrm{L}$ of competent cells to one of the pre-warmed $14 \mathrm{~mL}$ tubes of SOC.

11. Positive control: Add $1 \mu \mathrm{L}$ of a highly purified supercoiled $\mathrm{pUC} 18(10 \mathrm{pg} / \mu \mathrm{L})$ plasmid to $40 \mu \mathrm{L}$ of competent cells in one of the pre-chilled microcentrifuge tube. Follow steps $5-8$ but resuspend in $0.95 \mathrm{~mL}$ of $\mathrm{SOC}$ using the second $14 \mathrm{~mL}$ pre-warmed tube.

12. Plate on LB/GA plates: $100 \mu \mathrm{L}$ of the negative control; $100 \mu \mathrm{L}$ of $10^{-1}$ and $10^{-2}$ dilutions of the positive control; $100 \mu \mathrm{L}$ of $10^{-2}, 10^{-3}, 10^{-4}$ and $10^{-5}$ dilutions of each $50 \mathrm{~mL}$ conical tube (containing $12 \mathrm{~mL}$ of SOC and transformed bacteria).

13. Transfer the content of each $50 \mathrm{~mL}$ centrifuge tube ( $12 \mathrm{~mL}$ of $\mathrm{SOC}$ with transformed cells) in a 1 liter flask containing $200 \mathrm{~mL}$ of $2 \mathrm{xTY}$ with $2 \%$ glucose and $100 \mu \mathrm{g} / \mathrm{mL}$ Carbenicillin (see Note 1).

14. Incubate at $37{ }^{\circ} \mathrm{C}$ with shaking $(220 \mathrm{rpm})$ until $\mathrm{OD}_{600 \mathrm{~nm}}$ reaches 0.5 .

15. Add $20 \mu \mathrm{L}$ of KM13 helper phage at $10^{14} \mathrm{pfu} / \mathrm{mL}$ (20-fold excess).

16. Incubate for 30 min at $37^{\circ} \mathrm{C}$ without or with a slow shaking $(0-100 \mathrm{rpm})$.

17. Centrifuge at $3,000 \mathrm{~g}$ for $20 \mathrm{~min}$ at $4{ }^{\circ} \mathrm{C}$.

18. Resuspend each pellet in $500 \mathrm{~mL}$ of $2 \mathrm{xTY}$ with $25 \mu \mathrm{g} / \mathrm{mL}$ Kanamycin and $100 \mu \mathrm{g} / \mathrm{mL}$ Carbenicillin.

19. Incubate $\mathrm{ON}$ in a 2 liter flask at $37{ }^{\circ} \mathrm{C}$ with agitation $(220-240 \mathrm{rpm})$.

20. Calculate the size of the library and the transformation efficiency using the series of dilutions plated in step 12 (see Note 33).

21. Pool all the flasks and centrifuge for $30 \mathrm{~min}$ at $10,000 \mathrm{~g}$ at $4{ }^{\circ} \mathrm{C}$.

22. Recover the supernatant and add $1 / 5^{\text {th }}$ of the volume of PEG/NaCl $(200 \mathrm{~mL}$ per liter of supernatant). 
23. Incubate on ice in a cold room with regular mixing for at least $1 \mathrm{~h}$.

24. Centrifuge for $30 \mathrm{~min}$ at $10,000 \mathrm{~g}$ at $4{ }^{\circ} \mathrm{C}$ and discard the supernatant.

25. Spin briefly and eliminate any remaining drop of $\mathrm{PEG} / \mathrm{NaCl}$.

26. Resuspend all the pellets in a total volume of $300 \mathrm{~mL}$ of cold PBS with $15 \%$ glycerol.

27. Add $75 \mathrm{~mL}$ of $\mathrm{PEG} / \mathrm{NaCl}$ for a second precipitation and proceed as before (steps $23-26$ ); resuspend the pellet in $80 \mathrm{~mL}$ of cold PBS with $15 \%$ glycerol (see Note 34 ).

28. Centrifuge for $30 \mathrm{~min}$ at $10,000 \mathrm{~g}$ at $4{ }^{\circ} \mathrm{C}$ and recover the supernatant containing the phages.

29. Estimate phage concentration using UV absorbance with the formula: phages $/ \mathrm{mL}=\left(\mathrm{A}_{269 \mathrm{~nm}}\right.$ $\left.-\mathrm{A}_{320 \mathrm{~nm}}\right) \times 10^{13}$ (see Note 35$)$.

30. Aliquot in $50 \mu \mathrm{L}$ and store at $-70{ }^{\circ} \mathrm{C}$ (see Note 36 ).

\section{References}

1. P.A. Scolnik (2009) mAbs: a business perspective, mAbs. 1, 179-184.

2. J.M. Reichert (2012) Marketed therapeutic antibodies compendium, mAbs. 4, 19-21.

3. J.M. Reichert (2016) Antibodies to watch in 2017, mAbs. 0, 00-00.

4. W.R. Strohl (2014) Antibody discovery: sourcing of monoclonal antibody variable domains, Current Drug Discovery Technologies. 11, 3-19.

5. A.L. Nelson, E. Dhimolea, and J.M. Reichert (2010) Development trends for human monoclonal antibody therapeutics, Nature Reviews Drug Discovery. 9, 767-774.

6. A. Jakobovits, R.G. Amado, X. Yang, et al. (2007) From XenoMouse technology to panitumumab, the first fully human antibody product from transgenic mice, Nature Biotechnology. 25, 1134-1143.

7. A. Frenzel, T. Schirrmann, and M. Hust (2016) Phage display-derived human antibodies in clinical development and therapy, mAbs. 8, 1177-1194.

8. D.J. Schofield, A.R. Pope, V. Clementel, et al. (2007) Application of phage display to high throughput antibody generation and characterization, Genome biology. 8, R254.

9. P. Philibert, A. Stoessel, W. Wang, et al. (2007) A focused antibody library for selecting scFvs expressed at high levels in the cytoplasm, BMC biotechnology. 7, 81 .

10. G. Robin and P. Martineau (2012) Synthetic customized scFv libraries, Methods in molecular biology (Clifton, N.J.). 907, 109-122.

11. G. Robin, Y. Sato, D. Desplancq, et al. (2014) Restricted Diversity of Antigen Binding Residues of Antibodies Revealed by Computational Alanine Scanning of 227 Antibody-Antigen Complexes, Journal of Molecular Biology. 426, 3729-3743.

12. S.S. Sidhu and F.A. Fellouse (2006) Synthetic therapeutic antibodies, Nature Chemical Biology. 2, 682-688.

13. G. Johnson and T.T. Wu (2000) Kabat Database and its applications: 30 years after the first variability plot, Nucl. Acids Res. 28, 214-218.

14. T.A. Kunkel (1985) Rapid and efficient site-specific mutagenesis without phenotypic selection, Proceedings of the National Academy of Sciences of the United States of America. 82, 488-492.

15. P. Kristensen and G. Winter (1998) Proteolytic selection for protein folding using filamentous bacteriophages, Fold Des. 3, 321-8.

16. Supplementary protocols plasmid DNA, http://www.mn-net.com/tabid/12238/default.aspx. 
17. H.R. Hoogenboom, A.D. Griffiths, K.S. Johnson, et al. (1991) Multi-subunit proteins on the surface of filamentous phage: methodologies for displaying antibody (Fab) heavy and light chains, Nucleic Acids Research. 19, 41334137.

18. P. Martineau, P. Jones, and G. Winter (1998) Expression of an antibody fragment at high levels in the bacterial cytoplasm, J Mol Biol. 280, 117-27.

19. L.A. Day and R.L. Wiseman (1978) A Comparison of DNA Packaging in the Virions of fd, Xf, and Pf1, Cold Spring Harbor Monograph Archive. 08, 605-625.

\section{Figure legends}

\section{Figure 1. Schematic view of the experiment.}

The main steps of the protocol are depicted in the figure. (A) Production of uracil-containing ssDNA template in a dut ung E. coli strain (section 2.2); (B) Hybridization of the collection of mutagenic oligonucleotides and synthesis of the complementarity DNA strand using T7 polymerase and T4 DNA ligase (section 2.3); (C) Transformation in a $u n g^{+}$strain, elimination of the template ssDNA, and phage production originating from the newly synthesized mutant strand (section 2.5). (D) The boxes at the center of the figure illustrate the design of the mutagenic oligonucleotides. For each CDR an oligonucleotide is designed that hybridizes perfectly to each side of the CDR and with a central degenerate sequence covering the CDR. Each perfect-match is 10-20 nucleotide-long with a $\mathrm{Tm}$ of around $45^{\circ} \mathrm{C}$. The oligonucleotides are $5^{\prime}$-phosphorylated to allow ligation and thus closing of the DNA by the T4 DNA ligase. Many different designs are possible, in particular the degenerate sequence can only partially cover the CDR and use optimized mixes of bases or trinucleotide precursors to avoid stop codons and precisely define the resulting degeneracy.

\section{Figure 2. Quality control of the dsDNA synthesis.}

Efficacy of second-strand synthesis is analyzed by agarose gel electrophoresis. The ssDNA template (lane 1) migrates much faster in absence of intercaling agent than the dsDNA synthetized in section 2.3 (lanes 2 -9). In this example, eight mutagenesis experiments were performed in parallel with 8 VH-CDR3 loop lengths (indicated above the lanes). Because the analyzed DNAs are circular, their migration cannot be compared with the linear MW marker $(1 \mathrm{~kb}$ Generuler, Fermentas). 


\section{Notes}

1 Carbenicillin and Ampicillin can be alternatively used. However, since it is more stable, we prefer to use Carbenicillin for the last step of the library production (section 3.4). To make a stock solution of Carbenicillin or Ampicillin at $100 \mathrm{mg} / \mathrm{mL}$ final: dissolve $1 \mathrm{~g}$ of powder in 9 mL of $\mathrm{H}_{2} \mathrm{O}$, adjust to $10 \mathrm{~mL}$ with $\mathrm{H}_{2} \mathrm{O}$, sterilize by filtration, and store in aliquots at $-20{ }^{\circ} \mathrm{C}$.

2 We use here KM13 helper phage that confers resistance to kanamycin. M13KO7 or another helper phage can be alternatively used.

3 The quality of the PEG is critical (e.g., PEG 8000 for molecular biology from Sigma \#81268).

4 Nucleospin plasmid kit can be used to purify single-stranded M13 DNA. Macherey Nagel provides an additional protocol for this application that can be downloaded from their web site (16) or obtained on request. This protocol requires a buffer not present in the kit (NT2, \#740597). Alternatively, phenol extraction and ethanol precipitation can be used (14).

5 Be sure that the tubes are resistant enough. Falcon (\#352070) and Corning (\#430290) branded $50 \mathrm{~mL}$ polypropylene conical centrifuge tubes are resistant to $16,000 \mathrm{~g}$.

6 If not refrigerated, put the centrifuge in a cold room. Phages are very stable even at high temperature but the expressed $\mathrm{scFv}$ are heat-sensitive.

7 E. Coli K12 CJ236 can be obtained from NEB. Streak out the strain on LB agar containing chloramphenicol $(15 \mu \mathrm{g} / \mathrm{mL})$ to ensure that you start with an $\mathrm{F}^{+}$host, but do not include chloramphenicol in liquid media.

8 The protocol is flexible enough to work with any antibody format (scFv, Fv, Fab, (Fab') ${ }_{2}$, VHH, etc.), but requires a phage or phagemid vector. The mutagenic oligonucleotides must be complementary to the encapsided (+) strand that can be either the coding or the non-coding strand depending on the cloning orientation. 
9 High quality oligonucleotides must be used. The best is to order cloning-quality 5'phosphorylated oligonucleotides.

10 TG1: supE thi-1 $\Delta($ lac-proAB $) \Delta($ mcrB-hsdSM $) 5\left(\mathrm{r}_{\mathrm{k}}{ }^{-} \mathrm{m}_{\mathrm{k}}{ }^{-}\right)\left[\mathrm{F}^{\prime} \operatorname{traD} 36\right.$ proAB lacl $\left.{ }^{q} \mathrm{Z} \Delta M 15\right]$. For phage display it is critical to check for F' presence. For this reason you must keep TG1 on a synthetic plate without proline ( $\operatorname{rro} A B)$, for instance M9 plates with glucose and thiamine (thi-1). Use a recently streaked plate of less than 1 week.

11 BioRad $0.2 \mathrm{~cm}$ gap cuvettes allow the electroporation of $400 \mu \mathrm{L}$ of cells. Other brands are possible but check the size of the cuvette.

12 cfu: colony-forming unit. We use a large excess of bacteria to ensure that all the phages can infect a bacterium.

13 We use glucose in all the plates because the $\mathrm{scFv}$ is under the control of the lac promoter in pHEN1. This ensures a strong repression of the gene and avoid toxicity. You should get 1001000 colonies.

14 At an $\mathrm{OD}_{600 \mathrm{~nm}}$ of 0.5 , you should have around $5 \times 10^{8}$ bacteria/mL. To infect all the bacteria, a 20-fold excess of phages is used, that is $10^{10} \mathrm{KM} 13$ per $\mathrm{mL}$ of culture.

15 Avoid vigorous shaking but a slow shaking (100 rpm) is also possible.

16 Empty the supernatant into a liquid trash by inverting the tube, then, without reverting it, place the tube open upside down on a piece of paper towel to absorb the remaining liquid.

17 Clean the hood with phagospray and use filtered pipette tips to prevent contaminations with filamentous phages.

18 The pellet may be absent since it is essentially due to bacteria that were not fully eliminated by the first centrifugation step. 
19 When using a $1 \mathrm{~cm}$ path length, a $33 \mu \mathrm{g} / \mathrm{mL}$ solution of single-stranded DNA has an absorbance of 1 at $260 \mathrm{~nm}$. The yield should be around $75 \mu \mathrm{g}$. This is enough for three largescale mutagenesis experiments.

20 We usually use a single mutagenic oligonucleotide for the CDR1s, CDR2s and the VL-CDR3, and a series of oligonucleotides of different lengths for the VH CDR3. We prepare one mix for each VH-CDR3 length (10 $\mu \mathrm{L}$ of each oligonucleotide) to ensure an equal representation of the CDR3 lengths in the library. You can however mix together all the oligonucleotides if you need a library of a more limited size.

21 pHEN1-13R4 vector is 5229 bases long. If your phagemid contains $\mathrm{N}$ bases, 15 pmoles of ssDNA represents $\left(15 \times 330 \times \mathrm{N} \times 10^{-6}\right) \sim \mathrm{N} / 200 \mu \mathrm{g}$.

22 It is extremely important to cool down very quickly from $90{ }^{\circ} \mathrm{C}$ to $4{ }^{\circ} \mathrm{C}$ to avoid a hybridization bias due to a partial matching between the degenerated oligonucleotide and the original CDR sequence. You can use a thermal cycler or simply boil your sample and transfer it directly into an ice bucket. The third step at $45{ }^{\circ} \mathrm{C}$ is to remove wrongly hybridized oligonucleotides with a low Tm.

23 This is a very high dNTP concentration, much higher that what is used in most protocols $(0.1$ $-0.6 \mathrm{mM})$. With the classical dNTP concentrations, we only get few dsDNA. For the ssDNA given in this protocol, at least $1.25 \mathrm{mM}$ is required.

24 This is page 23 of the current manual. You can also heat-inactivate the reaction and purify by precipitation.

25 See section 2.5 "Elution procedures" in the Macherey-Nagel manual. 
26 Intercalating agents change the DNA supercoiling state and the migration speed. Resolution of single and double-stranded DNA is much better in their absence. For 1 liter of TAE x50: Tris $242 \mathrm{~g}, 57.1 \mathrm{~mL}$ acetic acid, $100 \mathrm{~mL}$ EDTA $0.5 \mathrm{M}, \mathrm{pH} 8.0(\mathrm{NaOH})$.

27 SYBR Safe DNA Gel Stain (Thermofisher). Any DNA stain can be used, e.g. Ethidium Bromide.

28 Alternatively you can use electrocompetent TG1 from Lucigen. You can contact them to get bulk quantities $(12 \times 500 \mu \mathrm{L})$.

29 Do not use ice but an ice/water mix to optimize temperature exchange.

30 We use a $10 \mathrm{~mL}$ pipette to avoid stressing the bacteria by shearing. You can use a $1 \mathrm{~mL}$ micropipette by cutting the tip at around $5 \mathrm{~mm}$ from the extremity. With the volume of competent cells prepared here you can perform up to six large electroporation experiments.

31 See figure 7 in the Biorad technical note MC1652101C (http://www.biorad.com/cmc_upload/Literature/12864/M1652101C.pdf).

32 The period between applying the pulse and transferring the cells to the outgrowth medium is critical for efficient recovering of E. coli transformants. Delaying this transfer by even one minute causes a threefold drop in transformation efficiency.

33 If the library is not large enough and the transformation efficiency lower than $5 \times 10^{9}$ you must improve electrocompetent cell preparation or use commercial ones. If the cells are competent enough, the problem comes presumably from the dsDNA preparation (section 2.3). Check the efficiency of this step by analyzing your sample on an agarose gel: no ssDNA but a strong dsDNA band should be visible (Figure 2).

34 This volume is suitable if you have pooled 5-10 transformations. You can scale it down or up depending on the anticipated results (see Notes 35 and 36). 
35 The formula depends on the phage/phagemid size (19). Phages/mL $=\left(A_{269 n m}-A_{320 n m}\right) \times 6 \times$ $10^{13} /$ (number of bases of the phage ssDNA). It is better to also titer the infectious phages using serial dilutions, infection of mid-log TG1, then plating on LB/GA (cfu/mL). In general, infectious phages represent 10-50\% of the UV-determined particles; e.g., in one of the library made in the group, we obtained at this step $2.2 \times 10^{14}$ phages $/ \mathrm{ml}$ using UV and $3 \times 10^{13}$ cfu/mL by titration.

36 Each aliquot should be a hundred times larger than the library size measured by titration. For most libraries this means around $10^{12}$ phages. It is convenient to aliquot into strips of $8 \times 0.2$ $\mu \mathrm{L}$ PCR tubes. 